\title{
Evaluating the final military phase of the Border War in South-Eastern Angola 1987 -1988
}

\author{
Janet Szabo \\ The $S A B C$
}

\begin{abstract}
The assessment of the final military phase of South Africa's border war in southern Angola from 1987 to 1988 in terms of victory or defeat is not without controversy. The mobile engagements on the Lomba between the South Africans (in support of UNITA) and the Angolan armed forces (FAPLA), saw a clear victory for the SADF when assessed in terms of achievement of objectives, equipment captured and destroyed as well as enemy casualties. South Africa's offensive manoeuvres on the Chambinga River - particularly regarding the Angolan $16^{\text {th }}$ Brigade as more recent information indicates - were also successful in inflicting significant losses of men and equipment and damaging morale. However, once the SADF switched from mobile warfare - which allowed it to effectively engage the Angolans who had superior numbers - to positional warfare against larger numbers of Angolan and Cuban forces in well-prepared and defended positions at Tumpo opposite Cuito Cuanavale, the picture changed. Tumpo can thus be regarded as a stalemate. South Africa had achieved its objective of preventing UNITA's annihilation and inflicted sufficient losses on FAPLA. But it had not managed to completely dislodge the Angolan and Cuban forces from the east bank of the Cuito River.
\end{abstract}

\section{Introduction}

Although 30 years have passed since the final military phase of South Africa's Border War in south-eastern Angola in 1987 and 1988, the facts are still largely unknown and as a result, frequently misrepresented. The events have been portrayed variously as a decisive defeat for the South African Defence Force (SADF) and therefore a colossal victory for the Angolan and Cuban forces; a stalemate or a tactical withdrawal by the SADF.

While politicians, soldiers and the general public favour accounts of epic battles, resulting in decisive victories or defeats, the reality - particularly in this case - is not as clear cut. British military historian Michael Howard suggests that because war is sporadic and clearly defined - unlike politics or economic activity which are ongoing and constantly evolve - there are clear criteria for success or failure. ${ }^{117}$ In evaluating victory or defeat, strategists frequently refer to defeat mechanisms and use terms such as annihilation, attrition, dislocation (rendering the enemy's strength irrelevant) and exhaustion.

Attrition focuses on killing soldiers and destroying equipment until the enemy can no longer fight. Dislocation focuses on the state of mind of the enemy leadership, 
while disintegration targets the will of combatants and disrupts their ability to function as a cohesive body. ${ }^{118}$

Hans Delbrück, the 19th-century German military historian, drew a fundamental distinction between strategies based on the annihilation of an opponent and those aimed at exhausting the enemy through manoeuvre so that he accepts the conditions of surrender. ${ }^{119}$ Former United States Air Force officer and air power theorist, Colonel John Warden, in his five rings theory of strategic military attack, and the British military historian and theorist, Basil Liddell Hart, in his strategy of the indirect approach, indicate that one, well-placed attack can cause so much psychological damage as to have a decisive strategic effect regardless of the physical damage. ${ }^{120}$ The Prussian general and military theorist, Carl von Clausewitz, cites the improbability of victory and unacceptable costs as additional grounds for making peace. ${ }^{121}$ Defeat mechanisms for an attack and a defence also differ. ${ }^{122}$

This article will assess the engagements of 1987 and early 1988 in terms of victory or defeat at tactical and operational level. It will look at the statistics (losses of men and equipment of both FAPLA and the SADF) and whether this had a significant impact on both sides' abilities to achieve their objectives, as well as morale and command and control functions. It will however not deal in any detail with the diplomatic and political processes which have been widely covered in other works.

\section{Early South African involvement in southern Angola}

South Africa's involvement in southern Angola since Operation Savannah in 1975 was driven and escalated by regional and international Cold War politics. What began as a clandestine operation to assist the National Union for the Total Independence of Angola (UNITA) recover its lost territory, intensified over the years as the then Soviet Union, Cuba and several other former East Bloc countries stepped up their involvement in support of the Popular Movement for the Liberation of Angola (MPLA) and the South West African People's Organisation (SWAPO) which was then fighting for Namibian independence from South Africa. ${ }^{123}$

After 1976 when South Africa withdrew from southern Angola following international pressure, SWAPO emerged stronger than before. It had the additional advantage of a safe haven in southern Angola from which to operate following an alliance with the MPLA which allowed SWAPO to move closer to the People's Armed Forces of Liberation of Angola (FAPLA) bases. ${ }^{124}$

South Africa needed UNITA's continued presence in the south-eastern Cuando Cubango province to ensure that its counter-insurgency operations against SWAPO were confined and that they were unable to cross into the Caprivi or Kavango from Angola. Between 1978 and 1987, the SADF conducted numerous small-scale and several larger hot pursuit operations against SWAPO (Reindeer 1978; Sceptic 1980; Protea 1981; Askari 1983/84). Although these were largely successful, FAPLA continued to support SWAPO. ${ }^{125}$ 
From 1983 with Operation Karton, a pattern began to emerge, and this became clearer with operations Wallpaper (1985) and Alpha Centauri (1986). FAPLA focused on destroying UNITA through planned attacks on its stronghold of Mavinga. This was critical as it could be used as a springboard for an assault on UNITA's headquarters at Jamba. The attacks were launched from Cuito Cuanavale which was situated on the Old Portuguese Road and close to the only bridge over the deep and fast-flowing Cuito river. The settlement also had a vital airfield.

Following FAPLA's Operation Second Congress in 1985, UNITA appealed to South Africa for help. This led to a merger of the counter-insurgency fight and the Angolan civil war and a direct confrontation between South Africa and the Cubans and Soviets. ${ }^{126}$

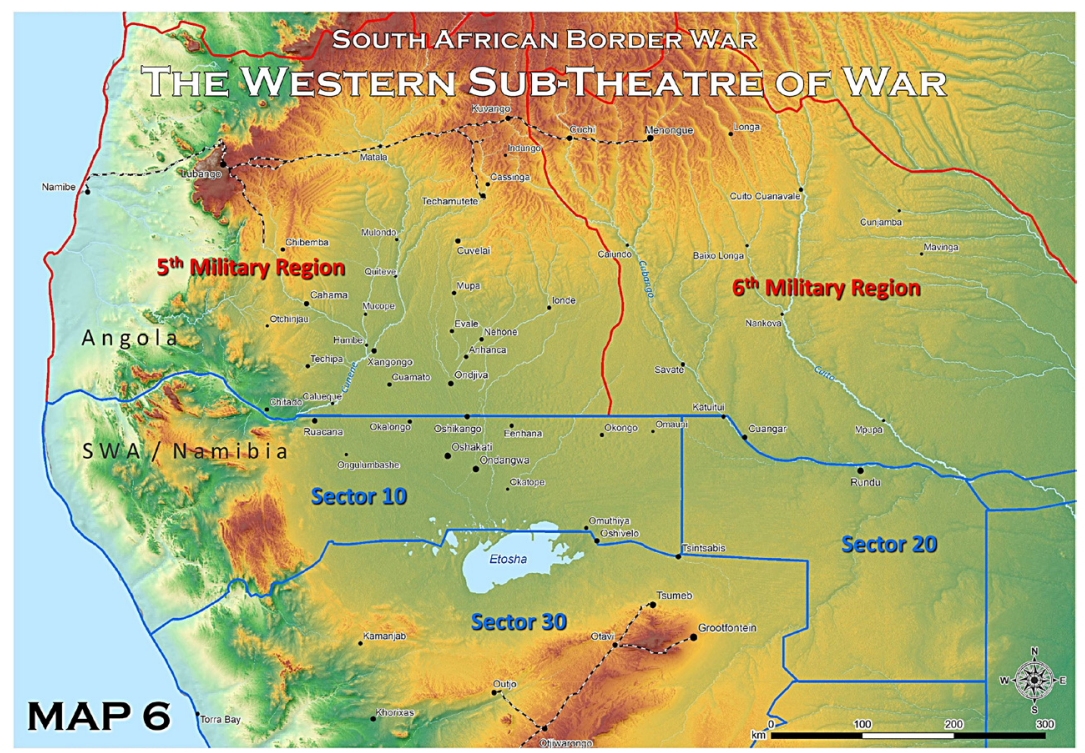

Angola ups the ante

In July 1987, FAPLA launched Operation Salute to October. This was a repeat of its failed 1985 Operation Second Congress. However, it included more powerful anti-aircraft weapons to counter the SADF's dominance of the air space (this made SADF ground operations more challenging) and other modern Soviet equipment never before seen by the West. This had been re-routed from Afghanistan where the Soviets were withdrawing. ${ }^{128}$ Operation Salute to October aimed at the annihilation of UNITA in the south-east, the destruction of its supply routes from neighbouring Namibia to central Angola, the taking of Mavinga and finally, capture of Jamba. ${ }^{129}$ An additional motivation for a successful attack was securing a stronger negotiating position at talks which US Assistant Secretary of State for African Affairs, Chester Crocker, was preparing for from June. ${ }^{130}$ 
FAPLA's elite forces, comprising four reinforced brigades of 11400 men, plus 62 Soviet military advisers, as well as SA- 8 and SA-13 surface-to-air missiles, 80 tanks and artillery would make up the attacking forces. ${ }^{131}$ The $16^{\text {th }}$ and $21^{\text {st }}$ brigades would move east from Cuito Cuanavale and then head south and towards Mavinga. ${ }^{132}$ The $47^{\text {th }}$ and $59^{\text {th }}$ brigades would move south and south-east respectively towards Mavinga. The $13^{\text {th }}, 25^{\text {th }}$ and $66^{\text {th }}$ brigades defended Cuito Cuanavale. The $8^{\text {th }}$ Brigade, which was later strengthened following SADF and UNITA attacks, moved supplies and equipment from Menongue, $192 \mathrm{~km}$ to the west, to Cuito Cuanavale. ${ }^{133}$

The SADF had been expecting an attack since early 1987 after South African military intelligence intercepted a letter from Angolan President Jose dos Santos asking an American lobby group to prepare officials in the US for an attack on UNITA. ${ }^{134}$ In response, they launched Operation Moduler on 13 August 1987.

\section{South Africa answers with Moduler}

Operation Moduler saw the start of the high-intensity conventional battles pitting the SADF and UNITA against the Cubans, Soviets and FAPLA. It was fought along the Lomba River and between the Lomba and Chambinga rivers. One of the key political aims was to put pressure on Angola to negotiate with UNITA. ${ }^{135}$

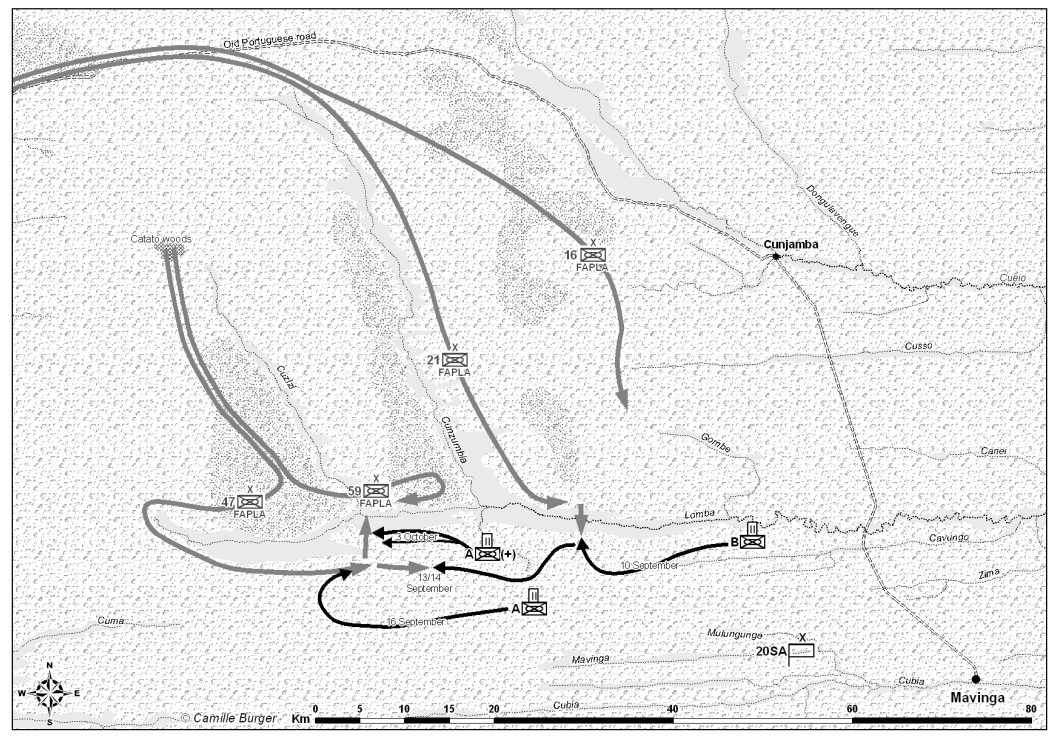

Terrain and climate were to play a major role in the SADF's mobility. ${ }^{136}$ This became a decisive factor in later operations. Retired Major General Roland de Vries, who was the Officer Commanding 61 Mechanised Battalion Group (61 Mech) and participated during operations Moduler (1987) and Prone (1988) says that because of the nature of the terrain, the SADF deliberately planned their operations to keep 
FAPLA guessing and attack them where they were most vulnerable, or when they were least expecting it - for example at night. ${ }^{137}$ As time was a critical factor for the SADF, the focus was on speedily breaking down FAPLA's morale and its ability to attack Mavinga.

With growing international pressure, South Africa's operations in Angola had to be limited in terms of duration and objectives. ${ }^{138}$ South Africa's leadership was very reluctant to incur casualties and loss of equipment. It was also highly unlikely the superpowers would allow the country to wage a protracted conventional war against the Angolans, Soviets and Cubans for fear of the fighting escalating and drawing them in. ${ }^{139}$ This desire by both South Africa and Angola to avoid an escalation is also evident in the fact that there was no formal declaration of war from South Africa and that both sides largely left each other's strategic-level logistics alone. ${ }^{140}$ The CubanAngolan forces also did not attempt to cut the South Africans off from their support bases in Rundu and Mavinga.

Initially Moduler's objectives were very modest and focussed on providing limited support to UNITA to enable it to repel the FAPLA offensive. Assistance was limited to four companies of infantry from 32 Battalion, a $127 \mathrm{~mm}$ multiple rocket launcher (MRL) battery and $120 \mathrm{~mm}$ mortar troop and special forces. ${ }^{141}$

By mid-August it was clear that the initial force was insufficient. The SADF decided to increase it to full brigade strength, establishing 20 Brigade, and both 32 Battalion and 61 Mech were authorised to be used offensively. On 24 August, a special forces team from 4 Reconnaissance Regiment mounted Operation Coolidge to destroy the bridge over the Cuito River. However, it was only badly damaged. The emphasis on the bridge was to hit FAPLA where it was weak and cut its logistic and communication lines. However, this action had no long-term military effect; while no heavy equipment could cross the river, FAPLA were able to move other supplies by barge or helicopter. ${ }^{142}$ As FAPLA followed the highly centralised Soviet system, Cuito Cuanavale was used as a communication, command and support hub with its air strip and the only road and bridge over the Cuito River, making it a vital choke-point.

By the end of the first phase of Moduler on 5 October, the SADF had achieved an important victory on the Lomba, using manoeuvre tactics. This saw the extensive destruction of equipment, as well as large numbers of casualties, causing FAPLA to flee in disorder. Major Igor Zhdarkin, a Russian who served in Angola from 1986 to 1988, details the fear and flight of FAPLA in the face of the SADF attack. ${ }^{143}$ The SADF had annihilated the $47^{\text {th }}$ Brigade (it was removed from the Angolan order of battle) and reduced the $21^{\text {st }}$ and $59^{\text {th }}$ brigades to around a third of their original strength. ${ }^{144}$ FAPLA's losses included:

"61 tanks, 53 BTR-60 armoured personnel carriers, seven BMP-1 infantry fighting vehicles, 23 BRDM-2 reconnaissance patrol vehicles, 20 BM-21 rocket launchers, a sophisticated Soviet SA-8 missile system (captured intact), 1059 dead and 2118 wounded. South African losses stood at 17 
dead, 41 wounded, and three Ratel infantry fighting vehicles, two Casspirs, one Bosbok spotter aircraft and one Seeker unmanned aerial vehicle destroyed". ${ }^{145}$

Bridgland estimates that UNITA, essentially a guerrilla force and lacking formal records, lost around 1000 fighters between June and 4 October $1987 .{ }^{146}$ For the South Africans, the G-5 $155 \mathrm{~mm}$ towed guns and anti-tank Ratels proved to be the gamechangers. ${ }^{147}$ De Vries also puts it down to superior tactics, command and control and use of terrain. ${ }^{148}$

The FAPLA offensive against Mavinga had been halted without achieving any of its objectives. They had also suffered significant losses of men and equipment, which damaged morale. The four brigades, which had been defeated on the Lomba, were now retreating back to Cuito Cuanavale. The decision by senior South African military and political leaders to implement offensive plans for phases two and three of Moduler underlines this victory and is an indication that morale and expectations were high on the South African side. The political leaders now gave the SADF carte blanche and authorised the use of tanks to destroy FAPLA east of the Cuito and ensure it could not launch another attack against Mavinga in the next year. ${ }^{149}$ However, not all officers agreed with the decision to extend Moduler. One vocal opponent was Commandant J.J (Bok) Smit, the Officer Commanding 61 Mech, who was replaced during the further phases. ${ }^{150}$

FAPLA were now withdrawing to defensive positions to their rear that they had occupied almost two months earlier. However, they were still able to prepare for another attack on Mavinga. The $16^{\text {th }}$ and $21^{\text {st }}$ brigades were deployed at the source of the Chambinga River, while the $59^{\text {th }}$ which included elements of the smashed $47^{\text {th }}$ Brigade as well as a tactical group, were between the Vimpulo and Mianei rivers. ${ }^{151}$

\section{South Africa's turning manoeuvres on the Chambinga}

The SADF's objective was now to prevent FAPLA regrouping and launching another offensive on Mavinga by creating a mobile battle between the Lomba and Chambinga rivers and engaging and destroying the FAPLA brigades one by one. ${ }^{152}$ FAPLA's single brigades on the move and in relatively unfamiliar territory were deemed extremely vulnerable and easy to annihilate, especially while the memories of the encounters with the SADF and the fate of the $47^{\text {th }}$ Brigade were still fresh. The South Africans identified the $16^{\text {th }}$ Brigade as their first target and attacked on 9 November 1987. This was seen as strategic to FAPLA's command axis, logistics line and route to the Chambinga bridge. ${ }^{153}$ Also if it could be destroyed, the $59^{\text {th }}$ and $21^{\text {st }}$ brigades further east would be easy to attack and pick off. However, despite inflicting severe loses on the brigade, South Africa decided to break contact, allowing it to reorganise and cross the Chambinga bridge - the only escape route open to the brigades in the south - and so escape the fate of the $47^{\text {th }}$ Brigade. 


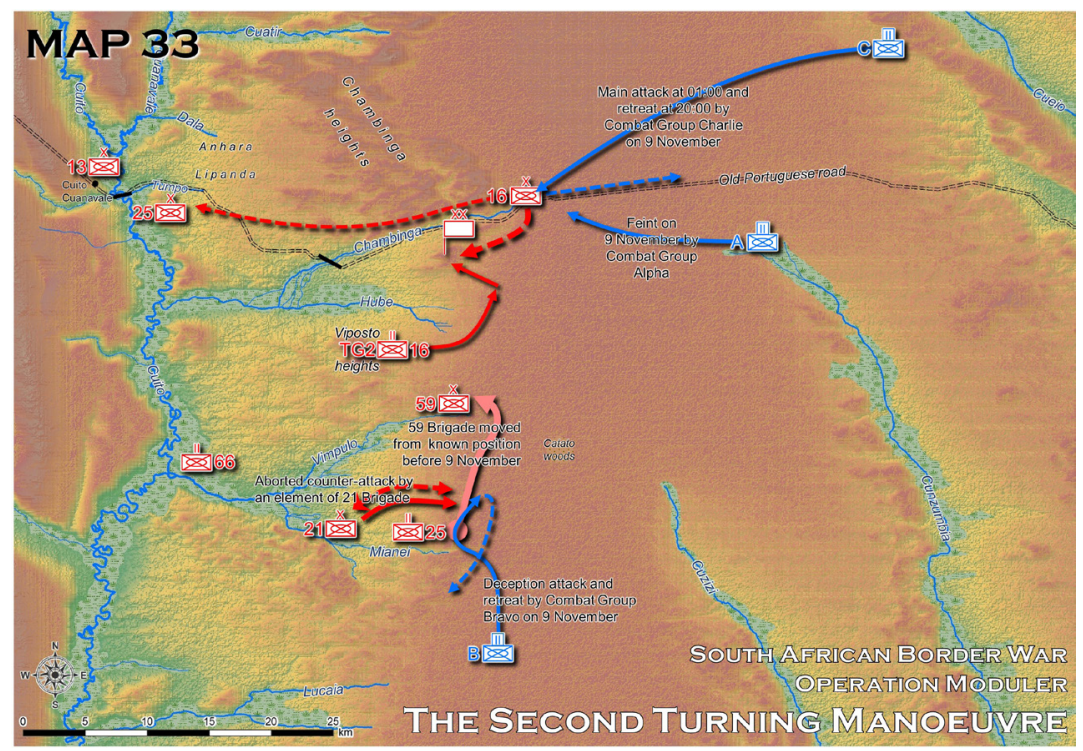

Leon Marais, commanding the SADF combat group that led the attack on the $16^{\text {th }}$ Brigade, indicates his mission was to cripple the brigade, not annihilate it. He pointed out he did not have sufficient force levels: he had a mechanised battalion group with two mechanised companies and an under-strength 32 Battalion company against FAPLA's brigade and at least one T-55 tank company in a defensive posture. The strength was 1:3 in FAPLA's favour. Marais says that despite criticism of the decision to break contact, the $16^{\text {th }}$ Brigade was unable to carry out significant operations during the rest of Moduler. ${ }^{154}$ Insufficient force levels were to plague the South Africans during most of their engagements against FAPLA in the following months and were directly linked to their failure to fully achieve their objectives.

More recent information translated from Russian, appears to vindicate Marais. It suggests that the $16^{\text {th }}$ Brigade "could no longer function as a co-ordinated formation under a single command". ${ }^{155}$

Although the SADF undertook further attacks on the retreating brigade, minefields, terrain, weather and bad luck worked against them. ${ }^{156}$ Despite the South Africans' attempts to stop them, the $59^{\text {th }}, 21^{\text {st }}$ and $25^{\text {th }}$ brigades were all able to cross the Chambinga bridge. Although FAPLA were only reacting to SADF actions, the brigades were still able to withdraw and the $59^{\text {th }}$ and $21^{\text {st }}$ brigades linked up ensuring that once again the SADF failed to fully achieve its objectives.

However, FAPLA suffered significant losses: about 525 FAPLA soldiers were killed, 28 tanks, ten BTR-60s, 85 logistics vehicles and three anti-aircraft missile systems were destroyed. ${ }^{157}$ The SADF also failed to prevent the brigades escaping 
north. SADF documents also indicate that despite the set-backs, the Angolans put up a fight. ${ }^{158}$ This was a clear indication that FAPLA had improved command and control systems and that morale was rising.

At this point the SADF was also losing momentum - an indication that it was failing in its objective to exhaust the enemy through manoeuvre. The soldiers were exhausted and frustrated that they could not stop FAPLA, plus the two-year conscription for most members of $61 \mathrm{Mech}$ and 4 SA Infantry Battalion in Angola would end in December (making them reluctant to engage in further fighting that could see casualties), and the equipment needed replacing and repairing. ${ }^{159}$ However, the time between engagements allowed FAPLA to regroup and resupply, both of which had a positive impact on morale.

But the SADF still had options. These included: bringing in more troops and equipment and moving west of the Cuito River (the current force would be withdrawn); exchanging troops in line; using existing forces in Phase Four. The last option was chosen because officers believed that FAPLA was 70 per cent defeated east of the Cuito. ${ }^{160}$ It appears that the SADF underestimated FAPLA's resilience and also the response from the Angolan leadership and Cuba as subsequent developments were to show.

The SADF leadership decided to stage one final attack on FAPLA over the Chambinga high ground, north of the Chambinga River. Through this they hoped to put sufficient pressure on FAPLA to withdraw across the Cuito River to Cuito Cuanavale on the west bank and open meaningful negotiations. ${ }^{161}$ There was also concern that after 10 December 1987, because political negotiations had reached a decisive point, international pressure could be exerted on South Africa to withdraw at the end of the month. ${ }^{162}$

The attack, which began on 25 November, marked the beginning of the end of the mobile warfare approach and the start of one of attrition which defined subsequent operations Hooper and Packer. The delay had again enabled FAPLA to pull back, regroup and prepare their defences with 300 Cubans deployed in support. ${ }^{163}$ FAPLA were no longer passive victims of attrition, dislocation and disintegration - they were able to prepare a response indicating they knew they had options and how to use them to their advantage.

Numbers favoured the defenders as did the terrain. De Vries notes: "FAPLA now defended terrain north of the Chambinga, which was extremely difficult to attack frontally with mechanised forces in the face of concentrated artillery and air power." 164

According to Scholtz, FAPLA had five brigades totalling 4000 to 5000 men and about 40 tanks, while the SADF had about 3000 men and 13 tanks. ${ }^{165}$ FAPLA had good indirect fire support and as they had moved back towards their own logistics, they had stretched the South African supply lines. ${ }^{166}$ The South Africans called off the attack as an accurate artillery bombardment, dense bush and a minefield had slowed 
them down and restricted their ability to manoeuvre. When Operation Moduler ended on 5 December 1987, it had halted the FAPLA offensive on the Lomba, inflicting significant losses and forced FAPLA to retreat to almost where their offensive had started around five months earlier. However, the South Africans had not been able to destroy the FAPLA brigades east of the Cuito

The loss of momentum once again allowed FAPLA to regroup, recuperate and bring up reinforcements and new equipment and to prepare the defences at Cuito Cuanavale and Tumpo for SADF attacks launched during operations Hooper and Packer. FAPLA were also now on familiar ground of their own choosing and their morale had improved. ${ }^{167}$ As the SADF was no longer able to exhaust the enemy through manoeuvre, it opted to deploy observers and leave artillery in place with a protection element to discourage renewed FAPLA attacks to the east. ${ }^{168}$

\section{The focus on Tumpo}

In withdrawing to the area around Tumpo, the defenders were stronger than the attacking forces. FAPLA were now reinforced by battle-hardened troops who had faced the SADF on the Lomba and Chambinga. Scholtz assesses Operation Moduler as "a victory on points, not a knockout." 169 While UNITA remained as a buffer against SWAPO infiltration into Kavango, FAPLA were still a threat to UNITA in the east, plus they now had a stronger motivation to resume the failed Salute to October at the first opportunity.
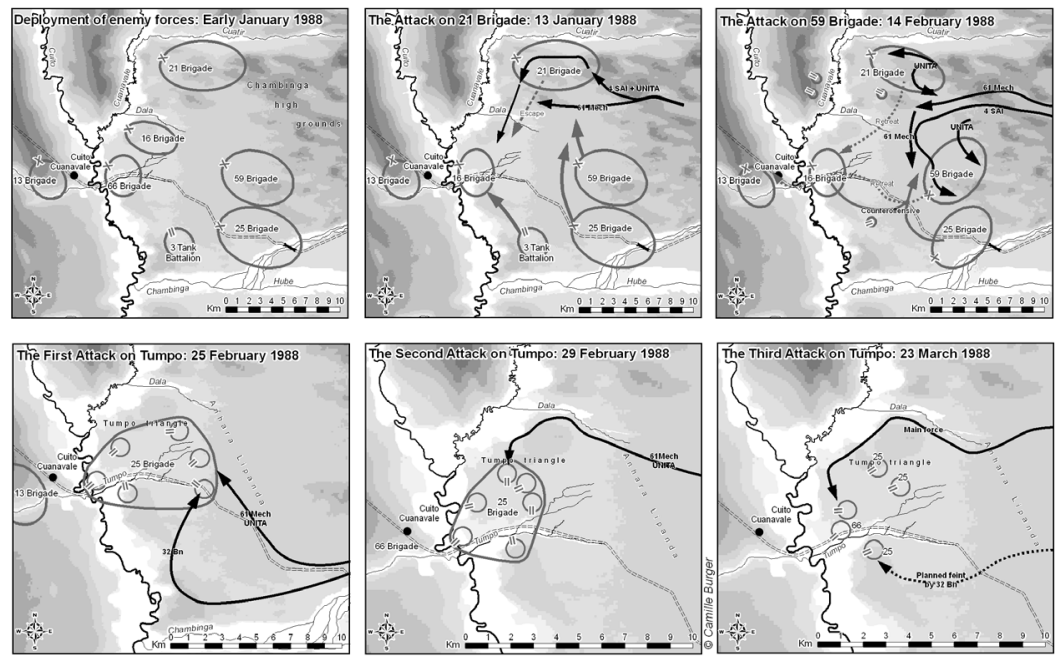

FAPLA had set up defences in Tumpo composed of three layers. The first, occupied by the $21^{\text {st }}, 25^{\text {th }}$ and $59^{\text {th }}$ brigades was anchored on the Cuatir River in the north, and the Chambinga in the south. The second, occupied by the $16^{\text {th }}$ and $66^{\text {th }}$ brigades and Tactical Group 2, was anchored on the Cuito-Dala confluence in the 
north and the Cuito-Chambinga confluence in the south. The third, occupied by the $13^{\text {th }}$ Brigade, a Cuban battalion and a divisional anti-aircraft brigade, was west of the Cuito River and centred on Cuito Cuanavale. Control of the artillery had also been centralised. ${ }^{170}$ In addition, Angolan President Jose Dos Santos had given permission for Cuban leader Fidel Castro to personally take over operational command. Castro sent his elite $50^{\text {th }}$ Division to Angola, as well as more tanks and mechanised infantry to Cuito Cuanavale. ${ }^{171}$

This situation made a further South African operation necessary to clear FAPLA from the area between the Cuatir and Chambinga rivers so that UNITA could hold the terrain east of the Cuito. Recent research in the Department of Defence archives has established that the SADF was specifically ordered not to fight to take Cuito Cuanavale; occupation was only considered as an option if the Cubans and FAPLA withdrew. ${ }^{172}$ The first full-scale South African attack of Operation Hooper began on 13 January 1988. Bridgland notes that the SADF and UNITA forces had been reorganised ensuring that around 2000 men and 24 tanks would move from the east of the Cuito to take on five FAPLA brigades east of the river as well as three to the west. ${ }^{173}$

The attack focused on the $21^{\text {st }}$ Brigade's position with the objective to clear FAPLA from the area east of the Cuito and north of the Dala. Again the statistics were in the SADF's favour: FAPLA lost about 150 soldiers, seven tanks were destroyed and five captured, two rocket launchers and three 23-mm guns were destroyed. UNITA suffered four dead and 18 wounded while South Africa reported one damaged Ratel and one soldier wounded. ${ }^{174}$ The $21^{\text {st }}$ Brigade abandoned its positions which were then occupied by UNITA. But despite these impressive statistics, the SADF was unable to exploit its gains because of insufficient troop and tank numbers, making it a draw operationally.

However, by the end of January the 21st Brigade reinforced by elements of the $8^{\text {th }}$ Brigade had pushed UNITA out. In contrast to FAPLA's disorder and flight on the Lomba, this indicated not only improved morale and ability to fight as cohesive units, but also better communications and command and control. The South Africans were not able to properly exploit the gap in the Angolan defensive line or use manoeuvre tactics to exhaust and dislocate their opponents. FAPLA were also improving their defences east of the Cuito through minefields and defensive artillery positions and conducting night operations. ${ }^{175}$ These had previously been the SADF's strong point.

In response, Cuban leader Fidel Castro ordered the best Cuban pilots, about 200 advisers, a tactical group of tanks as well as artillery and mechanised infantry to the front. ${ }^{176}$ To avoid a similar breakthrough to the one involving the $21^{\text {st }}$ Brigade earlier, the $59^{\text {th }}$ and $25^{\text {th }}$ brigades were ordered to pull back to better fortified positions. 


\section{Tumpo stalemate}

With the re-occupation of the $21^{\text {st }}$ Brigade's position, further SADF action became necessary. Unfavourable weather and logistics delays put the attack off until 14 February, again giving FAPLA time to prepare. ${ }^{177}$ Now the SADF's effort was on the $59^{\text {th }}$ Brigade - the strongest force in the centre of the outer defences - as they felt if this brigade withdrew, this would force the $25^{\text {th }}$ Brigade to the south and the $21^{\text {st }}$ Brigade in the north to pull back into the Tumpo Triangle. ${ }^{178}$

With this action which saw the $59^{\text {th }}$ Brigade cross the Cuito and the $21^{\text {st }}$ Brigade withdraw to Tumpo, the SADF had almost achieved its objective. Now FAPLA and the Cubans only controlled a small, but very well-defended area around Tumpo on the Cuito's east bank. In the fighting the two brigades lost around 230 soldiers, nine tanks, four BRDMs, seven 23-mm guns, five BM 21s and one SA 9. The SADF archives indicate 32 Cubans were also killed. The South Africans lost four 61 Mech members while 11 from $61 \mathrm{Mech}$ and 4 SAI were wounded. Two Ratel 20s, two tanks and one Ratel 90 were damaged. ${ }^{179}$ The SADF again handed the positions over to UNITA.

In Tumpo, FAPLA was now sacrificing terrain to strengthen its position and hold the SADF off, thus buying time. In the smaller area, the SADF had to attack FAPLA head-on and in an area where they were expecting to be engaged. The SADF was now breaking its rules applied successfully in Operation Moduler of attacking where the enemy was weak and where it least expected to be hit. FAPLA had now forced the SADF to change tactics and fight on its terms, indicating a stalemate was on the cards.

At Tumpo, FAPLA and the Cubans now had the advantage over the South Africans. Their strength lay in positional warfare and larger numbers. They were also fighting in an area of their choosing, closer to their own logistics and had cleared the vegetation to establish interlocking fields of fire and laid substantial minefields. They were unlikely to be driven out easily. ${ }^{180}$ Unable to take advantage of their strength in manoeuvre, the South Africans were incurring casualties and damage to equipment without achieving their objectives. This, plus the length of time the SADF was in Angola would in the long run affect morale, while its ability to exhaust FAPLA and the Cubans through attrition was also reduced.

The terrain of the Tumpo Triangle is worth noting. Scholtz and Bridgland have described it as being about 30 square kilometres, bordered on three sides by rivers making it easily fortified. The western side of the Cuito River, which is higher than the east bank, provided excellent citing for artillery emplacements. ${ }^{181}$ From these heights there is a clear view across the flat and almost treeless area known as the Anhara Lipanda which is about four to six kilometres wide and stretches to the start of the Chambinga high ground. ${ }^{182}$

While the main focus of the South Africans' efforts was on a direct confrontation at Tumpo, there were smaller, clandestine efforts by 32 Battalion and special forces to disrupt FAPLA's command and control and logistics west of Cuito Cuanavale. 
However, because of their size and small troop commitment, these did not have significant impact.

Because FAPLA still retained a bridgehead at Tumpo, the SADF believed a further attack was necessary to prevent renewed operations being launched against Mavinga and Jamba. The first of South Africa's three Tumpo engagements began on 25 February. This established a pattern whereby the South Africans were held at a distance - through minefields and artillery fire - and not able to engage FAPLA and the Cubans directly. ${ }^{183}$ This meant they were no longer able to exhaust FAPLA and destroy their equipment. However, the South Africans were now spending longer in Angola without achieving their objectives, affecting not only troop morale but also convincing the leadership that the initial objectives would have to be scaled down when, not if, the SADF withdrew. ${ }^{184}$

In this attack, the SADF encountered a minefield, alerting FAPLA to their presence, who in turn directed heavy artillery fire on the South African positions. The G-5 guns were unable to respond because of Soviet MiG fighters which provided air cover. ${ }^{185}$ Only 32 Battalion, early in the attack, came into direct contact with FAPLA or the Cubans. ${ }^{186}$ The attack failed, again increasing FAPLA's morale.

The second attack on Tumpo began on 1 March. Its objective was to destroy the Cubans and FAPLA at the bridgehead or drive them west over the Cuito River and destroy the bridge. ${ }^{187}$ Again the attack failed due to minefields and stand-off artillery fire. This marked the end of Operation Hooper and the main force withdrew. Once again, the SADF was frustrated in achieving its objectives and had to exercise other options to see that its gains were not reversed. A small force - less than 1500 -plus artillery were left in place to prevent FAPLA pushing east from Tumpo to re-occupy the $59^{\text {th }}$ Brigade's positions or threaten UNITA. ${ }^{188}$

At this point, the SADF leadership was becoming concerned at the length of time the troops had spent in Angola. This raised the inevitable question of withdrawal and how it could be done in a way that did not benefit either FAPLA or the Cubans and did not sacrifice the SADF's gains. ${ }^{189}$ This also marked a critical movement in the international negotiations as the focus shifted from the battlefield to the negotiating table. In an unprecedented direct offer to the Soviets in early March, Defence Minister Magnus Malan stated that if they agreed to install a genuinely non-aligned government in Angola, his government would not push for it to be friendly to South Africa. ${ }^{190}$ Although nothing concrete came of this overture, it set the scene for direct negotiations with South Africa amid the recognition that the implementation of UN Resolution 435 and South West African independence should be linked to Cuban withdrawal from Angola - a point the South Africans had long been insisting on. This shift in the political arena is clearly indicative that although South Africa had not achieved all its military objectives, it had certainly not been defeated militarily and was therefore able to negotiate from a position of strength. 
It was against this backdrop, that the third and final attack on Tumpo (Operation Packer) took place on 23 March 1988. The SADF felt that FAPLA still posed a threat to UNITA and following a morale boost from the two successful defences of Tumpo, would try to move east again. The SADF also had evidence that FAPLA wanted to take control of the Chambinga high ground. ${ }^{191}$ The attack was planned despite criticism and definite scepticism among several senior SADF officers and those who were tasked with its planning. ${ }^{192}$ The plan was similar to that of the failed 1 March attack. This would mean the SADF had to attack along a predictable route where FAPLA were anticipating an attack. The Angolans and Cubans had effectively used terrain to limit the South Africans' options.

Once again the South Africans were unable to close with the enemy, held at a distance by minefields and heavy, accurate artillery fire. Three SADF tanks were severely damaged by mines. These were the only ones lost in Angola. Although instructions had been issued at the start of Operation Moduler to ensure that no soldier or equipment fell into enemy hands, the tanks were not destroyed. General Andreas "Kat" Liebenberg ordered that they be recovered later, thereby handing the Cubans and FAPLA a propaganda coup when they recovered them. ${ }^{193}$

After several hours of fierce fighting, the SADF once again withdrew - suffering no casualties - without completing their objectives to drive the Cubans and FAPLA from the east bank. This unsuccessful attempt also convinced the leadership that it would not be possible to take Tumpo without high casualties and many more troops - both of which they were not prepared to risk. While FAPLA and the Cubans could record this as a tactical victory, it is worth noting that they did not follow this up with a counter-offensive against the South Africans.

Although Operation Packer ended on 27 March 1988, this did not see the South Africans withdraw from the area completely. Under Operation Displace, a smaller force of around 1000 conducted deception actions such as laying extensive minefields between the Chambinga and Cuatir rivers and carrying out other actions to give the impression the force was still at brigade strength. ${ }^{194}$ One example was artillery strikes on FAPLA attempts to repair the bridge over the Cuito on 29 March. ${ }^{195}$

Operation Displace only ended in August when conventional fighting in Angola ceased. Then the last South African soldiers withdrew to South West Africa. This operation effectively kept the Cubans and FAPLA guessing as to the South Africans' intentions. At least 12 FAPLA brigades remained tied down at Menongue and west of the Cuito in case South Africa staged another attack either on Tumpo from the south, or on Cuito Cuanavale. ${ }^{196}$ The South Africans also used the threat of further attacks and their presence in south-eastern Angola as an effective bargaining chip in the ongoing political negotiations. ${ }^{197}$ 


\section{Conclusion}

Although the SADF was swiftly able to fully achieve its objective of halting FAPLA's advance on Mavinga during the first phase of Operation Moduler, further attacks during the latter part of Moduler were only partially successful despite a campaign of attrition, dislocation and annihilation. In this regard, while the physical damage the SADF was able to inflict on FAPLA and the Cubans were impressive, these numbers only provided part of the picture. De Vries gives a succinct summary: on the Cuban and Angolan side 4085 soldiers died, while more than 194 pieces of armour, 92 pieces of other military hardware, $9 \mathrm{MiG}$ combat aircraft and 9 Russian helicopters had been destroyed. The South Africans lost 47 soldiers, three Olifant tanks, five Ratels, five other types of vehicle, 1 Bosbok light reconnaissance aircraft and two Mirage combat aircraft were destroyed. UNITA lost around 3000 fighters. ${ }^{198}$

The South Africans' loss of momentum provided FAPLA with critical time to regroup and re-arm. When the South Africans were halted at Tumpo (Operations Hooper and Packer) this also provided an all-important boost to FAPLA's morale and again allowed them to re-organise and re-arm. Here Castro's intervention was critical to strengthening command and control and adjusting tactics to enable FAPLA to hold off the SADF (exchanging terrain for time), thus boosting morale. For the Angolans, they also reaped the benefits of being the underdog, by drawing Cuba in to become actively involved in the fight. The fact that the SADF was unable to take Tumpo was also a significant boost for the Angolans after their defeat on the Lomba and rout on the Chambinga. The more time the South Africans spent in Angola trying to achieve their objectives not only undermined their soldiers' morale, it also posed political risks and raised the prospect of escalating the conflict - neither of which were acceptable.

The fact that after March 1988, South Africa was able for several months to continue to deploy troops and conduct deception operations around Tumpo is a clear indication that it had not suffered a resounding tactical and operational defeat at the hands of Cuban and FAPLA forces. For the Cubans and FAPLA, the fact that they had not been able to eradicate UNITA and drive the South Africans out of the country, was an indication that they would continue to bleed unless they negotiated. This indicates a stalemate.

\section{Endnotes}

${ }^{117}$ Howard, M. The Causes of Wars and Other Essays. Cambridge, Massachusetts. 1983, 193

${ }^{118}$ DeLancy, DJ. Adopting the Brigadier General (Retired) Huba Wass de Czege Model of Defeat Mechanism Based on Historical and Current Need. Fort Leavenworth, Kansas: School of Advanced Military Studies, United States Army Command and General Staff College. 2001, 8 online at http://www. dtic.mil/dtic/tr/fulltext/u2/a393858.pdf Accessed 9 September 2018

${ }^{119}$ Delbrück, H., translated by Walter J. Renfoe Jr. History of the Art of War: Within the Framework of Political History, Vol. 1V. Westport, Connecticut: Greenwood Press. 1985, 294 
${ }^{120}$ Bartholomees, JB, Jr. The Issue of Attrition, Parameters, v.40, no.1, Spring, 2010. $5-19,8$

${ }^{121}$ Clausewitz, C von. On War, edited and translated by Michael Howard and Peter Paret. Princeton, New Jersey: Princeton University Press. 1976, 91

${ }^{122}$ US Combined Arms Doctrine Directorate. Command and General Staff College Student Text 100-40: Offensive and Defensive Tactics.Fort Leavenworth, Kansas: Command and General Staff College. 1999, 3-21

${ }^{123} \mathrm{Du}$ Preez, S. Avontuur in Angola. Die verhaal van Suid-Afrika se Soldate in Angola 1975-1976. Pretoria: Van Shaik. 1989, 27

${ }^{124}$ Saunders, GM. The Foreign Policy of Angola under Agostinho Neto. California: Naval Postgraduate School. 1983, 64-65 online at http://www.dtic.mil/ dtic/tr/fulltext/u2/a141609.pdf Accessed 8 September 2018

${ }^{125}$ Scholtz, L. The SADF in the Border War 1966-1989. Cape Town:Tafelberg. 2013, 247; Lord, D. From Fledgling to Eagle: The South African Air Force during the Border War. Johannesburg: 30 Degree South Publishers. 2008, 187

${ }^{126}$ Scholtz op. cit. p. 247

${ }^{127}$ All maps used with permission of the originator, Camille Burger, camille@valgis.co.za

${ }^{128}$ Turton, AR. Shaking Hands with Billy. Durban: Just Done Publications. 2010, 153; Steenkamp, W. South Africa's Border War 1966-1989. Cape Town:Tafelberg. 2016, 246

${ }^{129}$ Shubin, G, Zhdarkin I, Barabulya V and Kuznetsova-Timonova A. (eds.). Cuito Cuanavale: Frontline Accounts by Soviet Soldiers. Auckland Park, Johannesburg: Jacana Media. 2014, 7; Steenkamp op. cit. p. 246; Turton op. cit. p. 153

${ }^{130}$ Crocker, CA. High Noon in Southern Africa: Making Peace in a Rough Neighbourhood. Johannesburg: Jonathan Ball Publishers. 1992, 347

${ }^{131}$ Gleijeses, P. Visions of Freedom: Havana, Washington, Pretoria and the Struggle for Southern Africa, 1976-1991. Johannesburg: Wits University Press. 2013, 395; Scholtz op. cit. p. 265

${ }^{132}$ FAPLA used ordinal numbers to refer to its units while the SADF used cardinal numbers. This article will keep that distinction.

${ }^{133}$ De Vries, R. Eye of the Firestorm: Strength Lies in Mobility. Cape Town: Naledi. 2013, 634

${ }^{134}$ Eriksen, GE. Forged in Flames. Thesis presented for history honours degree. Rhodes University, Grahamstown South Africa. 2010, 50 online at www. scribd.com/doc/48564518/Forged-in-Flames Accessed 14 September 2018

${ }^{135} 61 \mathrm{Mech}$ online archive. AMI/IO/328/6/3 KOMOPSPLAN: OP MODULAR, 17 September 1987, online at http://www.61mech.org.za/uploads/mediafiles/ files/68.pdf

${ }^{136}$ De Vries, R. Art of War Programme Study Material. Lessons of the South African Border War. Original unpublished document provided by retired Major General Roland de Vries, 2016, 24 
${ }^{137}$ Ibid.

${ }^{138}$ Scholtz op. cit. p. 247

${ }^{139}$ De Vries, R and McCraig GI. 'Mobile Warfare in Southern Africa', Strategic Review for Southern Africa, August 1987, 11-20, 11

${ }^{140}$ De Vries, R, Burger C and Steenkamp W. Mobile Warfare for Africa. On the Successful Conduct of Wars in Africa and Beyond. Lessons Learned from the South African Border War. Vol. 1. Helion and Company Limited: Solihull, 2017, 99

${ }^{141}$ Department of Defence Archives (hereafter DOD Archives) JF Huyser Collection, Box 88, A concise history of Operation Moduler (Phase One) May-October 1987, 1

${ }^{142}$ Stiff, P. The Silent War: South African Recce Operations 1969-1994. Alberton:

Galago Publishing. 1999, 545; 61 Mech online archive. H LEER/D OPS/309/4 OP MODULER/ HOOPER Voorligting aan senior offisiere van die SAW oor Operasie Moduler/Hooper, 19 online at www.61mech.org.za/ uploads/mediafiles/files/199.pdf

${ }^{143}$ Shubin, G and Tokarev A. (eds). Bush War: The Road to Cuito Cuanavale. Soviet Soldiers Accounts of the Angola War. Auckland Park, Johannesburg: Jacana. 2001, 40

${ }^{144}$ Szabo, J. Was there really a Battle of Cuito Cuanavale? An evaluation of conflicting narratives based on original SADF documents. Thesis presented for Masters Degree. Kings College, London. 2017, 27

${ }^{145}$ Lord op. cit. p. 411; Szabo op. cit. p. 27

${ }^{146}$ Bridgland, F. The War for Africa: Twelve Months that Transformed a Continent. Gibraltar: Ashanti. 1990, 162

${ }^{147}$ DOD Archive. JF Huyser Collection, Box 88, A personal impression of Op Moduler (Phase One) based on a visit to 20 Brigade Forward HQ over the period 19-30 September 1987 - Maj. W Dorning, 5, 11; Ibid. Onderhoud met Kmdt Van Der Westhuizen oor die rol van artillerie in Op. Moduler, 2; Ibid. Interview with Col. J Harris OC 32 Battalion on his battalion's involvement in Op Moduler, 5

${ }^{148}$ De Vries, Burger and Steenkamp. op. cit. p. 84

${ }^{149}$ DOD Archive. JF Huyser Collection, Box 88. A personal impression of Op Moduler (Phase One) based on a visit to 20 Brigade Forward HQ over the period 19-30 September 1987 - Maj. W. Dorning, 20-21

${ }^{150}$ Scholtz op. cit. pp. 201-202

${ }^{151}$ Szabo op. cit. p. 28

${ }^{152}$ Scholtz op. cit. p. 283

${ }^{153}$ Ibid. p. 291

${ }^{154}$ Email from Leon Marais 7 September 2017 
${ }^{155}$ Scholtz, L, Die Slag van die Chambinga, 9 en 11 November 1987: 'n taktiese en operasionele ontleiding, LitNet Akademies, 28 November 2018 https:// www.litnet.co.za/die-slag-van-die-chambinga-9-en-11-november-1987n-taktiese-en-operasionele-ontleding/ accessed 20 December 2018; Shubin G, Zhdarkin I, Barabulya V,Kuznetsova-Timonova A. (eds) Cuito Cuanavale:Frontline Accounts by Soviet Soldiers. Auckland Park: Jacana Media. 2014. 102-104

${ }^{156}$ Szabo op. cit p. 29

${ }^{157} 61$ Mech online archive. H LEER/D OPS/309/4 OP MODULER/ HOOPER Voorligting aan senior offisiere van die SAW oor Operasie Moduler/Hooper, 30 158 Ibid.

${ }^{159} 61$ Mech online archive. H LEER/D OPS/309/1 DEMOBILISASIE OP MODULER DES 87, 28 Oktober 1987, online at http://www.61mech.org.za/uploads/ mediafles/files/65.pdf

${ }^{160} 61$ Mech online archive. TK HK RUNDU/309/1 MODULER TOEKOMSTIGE OPTREDE, NOV 87, http://www.61mech.org.za/uploads/mediafiles/ files/234.pdf

${ }^{161} 61$ Mech online archive. H LEER/D OPS/309/4 OP MODULER/HOOPER Voorligting aan senior offisiere van the SAW oor Operasie Moduler/Hooper, 29

16261 Mech online archive. SWAGM VHK/309/1 OP MODULER OP BEPLANNING VOLGENS H LEER RIGLYNE, 8 Desember 1987, online at http:// www.61mech.org.za/uploads/mediafiles/files/70.pdf

${ }^{163}$ Szabo op. cit. p. 32

${ }^{164}$ De Vries, R. Case Study Number 6-The Chambinga Battles - Turning Manoeurves. 2016, 24

${ }^{165}$ Scholtz op. cit. p. 307

${ }^{166}$ Szabo op. cit. p. 32

${ }^{167}$ De Vries op. cit. 2016, 25

${ }^{168} 61$ Mech online archive. H LEER/D OPS/309/4 OP MODULER/HOOPER

Voorligting aan senior offisiere van the SAW oor Operasie Moduler/Hooper, 31

${ }^{169}$ Scholtz op. cit. p. 309

${ }^{170}$ Steenkamp, W and Heitman H. Mobility Conquers: The Story of 61 Mechanised Battalion Group 1978-2005. Solihull: Helion and company Limited. 2016, 840

${ }^{171}$ Steenkamp op. cit. p. 260; Gleijeses op. cit pp. 406-410

172 Szabo op. cit. p. 37; 61 Mech online archive. H LEER/D OPS/309/4 OP MODULER/ HOOPER Voorligting aan senior offisiere van die SAW oor Operasie Moduler/Hooper, 40-41; 61 Mech online archive. 309/1 OP HOOPER22 December 1987, online at http://61mech.org.za/uploads/ mediafiles/files/191.pdf

${ }^{173}$ Bridgland op. cit. pp. 256-257 
${ }^{174}$ Scholtz op. cit. p. 324

${ }^{175} 61$ Mech online archive. H LEER/D OPS/309/4 OP MODULER/ HOOPER

Voorligting aan senior offisiere van die SAW oor Operasie Moduler/Hooper, 43-44; Szabo op. cit. p. 38

${ }^{176}$ Scholtz op. cit. p. 325

${ }^{177}$ Szabo op. cit. p. 39

${ }^{178}$ Scholtz op. cit. p. 327

${ }^{179}$ Ibid. p. 332; 61 Mech online archive. H LEER/D OPS/309/4 OP MODULER/

HOOPER Voorligting aan senior offisiere van die SAW oor Operasie Moduler/Hooper, 47-48

${ }^{180}$ Holt op. cit. pp. 84-85; Szabo op. cit p. 41

${ }^{181}$ Personal observation by the author during a tour of southern Angola with $61 \mathrm{Mech}$ veterans during May 2018

${ }^{182}$ Bridgland op. cit. p. 294; Scholtz op. cit. pp. 338-339; Szabo op. cit. p. 41

${ }^{183}$ Bridgland op. cit. p. 283

${ }^{184}$ Scholtz op. cit. p. 346

${ }^{185}$ DOD Archives. JF Huyser Collection, Box 92, Gesamentlike militere aksies deur RSA en UNITA magte teen FAPLA magte in die sesde militerestreek van Angola vanaf Desember 1987 tot Maart 1988, 142-148, paragraphs 535560

${ }^{186}$ Ibid. 148-150, paragraphs 561-569

${ }^{187}$ Ibid. 152 paragraph 582

${ }^{188}$ Szabo op. cit. p. 43; DOD Archives. JF Huyser Collection, Box 92, Ibid. 166, paragraph 635

${ }^{189}$ Szabo op. cit. p. 43

${ }^{190}$ Steenkamp op. cit. p. 271

${ }^{191}$ DOD Archives. JF Huyser Collection, Box 92, Packer Konsep 213 Mrt '88 - 24 Mei' 88,23

${ }^{192}$ Scholtz op. cit. pp. 352-353

${ }^{193}$ Ibid. p. 357

${ }^{194}$ Bridgland op. cit. p. 332

${ }^{195}$ DOD Archives. JF Huyser Collection, Box 92, Packer Konsep 213 Mrt '88 - 24 Mei' 88

196 Ibid.

${ }^{197}$ Szabo op. cit. pp. 46-47

${ }^{198}$ De Vries, R. Illusion of Victory. Plettenberg Bay, 31 May 2018. 3 